\title{
Growth and Optical Properties of Un-Doped and Oil Bean Doped Tin (II) Oxide
}

\author{
Iwueze Tochi Malachy, Okpala Uchechukwu Vincent, Onuchukwu Chika Christian
}

\begin{abstract}
Here, we studied growth and characterization of Tin (II) oxide doped with oil bean seed extracts. Tin (II) oxide was grown by reacting some quantities of aqueous Tin chloride and aqueous sodium hydroxide. Oil bean seeds were grinded, dissolved in distilled water, stirred, and sieved to remove the undissolved parts. Analytical grade glass slides were inserted in the beaker.Samples B6 was un-doped, B7 was doped with $0.2 \mathrm{ml}$ of oil bean extract, $\mathrm{B8}$ was doped with $0.3 \mathrm{ml}$ of oil bean extract, B9 was doped with $0.4 \mathrm{ml}$ ofoil bean extract and B10 was doped with $0.5 \mathrm{ml}$ of oil bean extract.Optical characterization showed that oil bean seed extract decreased the transmittance with peak $50 \%$ at wavelength of $800 \mathrm{~nm}$, but improved the absorbance of Tin (II) Oxide with peak above 0.5 at wavelength of $300 \mathrm{~nm}$. The reflectance was too low with maximum peak of 0.2 at wavelength of $800 \mathrm{~nm}$. Samples B7, B8 and B9 have no band gaps but samples B6 and B10 have band gaps of 3.8 and 3.9 respectively and as such can be used as refractory materials.

Index Terms - Tin II Oxide, Optical Properties, Oil Bean and Band gap.
\end{abstract}

\section{INTRODUCTION}

Thin film technology is one of the most thriving industry today because it plays a vital role in nearly all electronic and optical devices. It has been used as electroplated films for decoration and protection (Heaven 1970). An interesting thing in thin film technology is the changes that take place in the structural, morphological and optical properties of the material whenever impurity is introduced.

In this work, we studied the optical properties of un-doped and oil bean doped Tin II oxide using chemical bath method.Tin (II) oxide or stannous oxide $(\mathrm{SnO})$ is composed of tin and oxygen where tin has the oxidation state of +2 . It is of two forms; stable blue-black and metastable red (Zumdahl, 2009; World Health Organization, 2005). It has a tetragonal structure. It is predominantly used as a precursor in the manufacturing of other tin compounds or salts and as a reducing agent and in the creation of ruby glass. Cerium (III) oxide in ceramic form, together with Tin (II) oxide (SnO) are used for illumination with UV light, (Peplinski D.R. et-al., 1980).

\section{OIL BEAN SEED}

Oil bean is popular in Nigeria. It has several names such as Apara in Yoruba, Ugba (Igbo) and Ukana in Efik. It is a popular condiment and meat analogue among consuming populations, (Enujiugha and Akanbi, 2005). The seeds are dorso-ventrally flattered, hard, brown in colour and about 6 $\mathrm{cm}$ long and $3 \mathrm{~cm}$ wide (Achinewhu et al., 1998). It is a nutritious seed. When unfermented it contains traces such as poisonous alkaloid known as pauvine, small amount of caffexylpectrecine, a growth depressant bacteria such as E. coli and Staphylococcus aureus, as well as molds that produce mycotoxins in food. Therefore, it must undergo fermentation process to eradicate any unwanted toxins before consumption. It contains protein, annino acids (44\% protein with all twenty essential amino acids), phosphorus, magnesium iron, vitamins, calcium, manganese and copper. It is an excellent source of phyto nutrients such as tannins, alkaloids, flavonoids, sterols, glycosides and saponins. The process of fermentation removes most of these mineral and vitamins such as phosphorus that have harmful effect, (Achinewhu et al., 1998). African oil bean has medicinal value. Neuro logical disorder and other ailments can be corrected with oil bean seed (Akintayo and Bayer, 2002).

\section{EXPERIMENTAL DETAILS}

\section{Preparation of Oil Bean Seed Extract}

Hard shells of some quantities of oil bean were removed from the main seed, dried and crushed with manual grinding machine. After grinding, the particles were dissolved in 100 $\mathrm{cm}^{3}$ of distilled water and later sieved to allow the mixture to be in aqueous form.

$40 \mathrm{ml}$ of hydrated tin (II) oxide chloridewas mixed with 20 $\mathrm{ml}$ of sodium hydroxide to produce tin oxide as a byproduct.

$$
\begin{aligned}
& \mathrm{SnCl}_{2}(\mathrm{aq})+2 \mathrm{NaOH}(\mathrm{aq}) \rightarrow \mathrm{SnO}(\mathrm{aq})+ \\
& 2 \mathrm{NaCl}(\mathrm{aq})+\mathrm{H}_{2} \mathrm{O}(\mathrm{l})
\end{aligned}
$$

The mixture was placed in a magnetic stirrer at temperature of $60^{\circ} \mathrm{C}$ for 20 minutes.After which glass slides were immersed into the beaker containing the sample for 24 hours to allow deposition of tin (II) oxide to take place. $0.2 \mathrm{ml}, 0.3$ $\mathrm{ml}, 0.4, \mathrm{ml}$ and $0.5 \mathrm{ml}$ of oil bean seed extract were added to the samples; B7, B8, B9 and B10 respectively. Sample B6 was un-doped.

Table 1.1: The Summary of Experiment Conducted with Tin (II) Oxide Doped with Oil Bean Seed Extract

\begin{tabular}{lccc}
\hline Sample & $\mathrm{SnCl}_{2}(\mathrm{aq})$ & $\begin{array}{c}\mathrm{NaOH} \\
(\mathrm{aq})\end{array}$ & $\begin{array}{c}\text { Oil bean } \\
\text { seed extract }\end{array}$ \\
\hline $\mathrm{B}_{6}$ & $40 \mathrm{ml}$ & $20 \mathrm{ml}$ & Un-doped \\
$\mathrm{B}_{7}$ & $40 \mathrm{ml}$ & $20 \mathrm{ml}$ & $0.2 \mathrm{ml}$ \\
$\mathrm{B}_{8}$ & $40 \mathrm{ml}$ & $20 \mathrm{ml}$ & $0.3 \mathrm{ml}$ \\
$\mathrm{B}_{9}$ & $40 \mathrm{ml}$ & $20 \mathrm{ml}$ & $0.4 \mathrm{ml}$ \\
$\mathrm{B}_{10}$ & $40 \mathrm{ml}$ & $20 \mathrm{ml}$ & $0.5 \mathrm{ml}$ \\
\hline
\end{tabular}

Iwueze Tochi Malachy, Post Graduate Student, Department of Industria Physics, Faculty of Physical Sciences, Chukwuemeka Odumegwu University, Uli, Anambra State, Nigeria

Okpala Uchechukwu Vincent, Lecturer, Department of Industrial Physics, Faculty of Physical Sciences, Chukwuemeka Odumegwu University, Uli, Anambra State, Nigeria

Onuchukwu Chika Christian, Lecturer, Department of Industrial Physics, Faculty of Physical Sciences, Chukwuemeka Odumegwu University, Uli, Anambra State, Nigeria 


\section{Growth and Optical Properties of Un-Doped and Oil Bean Doped Tin (II) Oxide}

\section{OPTICAL ANALYSIS}

Here, optical properties of un-doped and oil bean doped tin II oxide were discussed. Samples B6 was un-doped, B7 was doped with $0.2 \mathrm{ml}$ of oil bean extract, B8 was $0.3 \mathrm{ml}$ of oil bean extract, B9 was $0.4 \mathrm{ml}$ of oil bean extract and B10 was $0.5 \mathrm{ml}$ of oil bean extract.

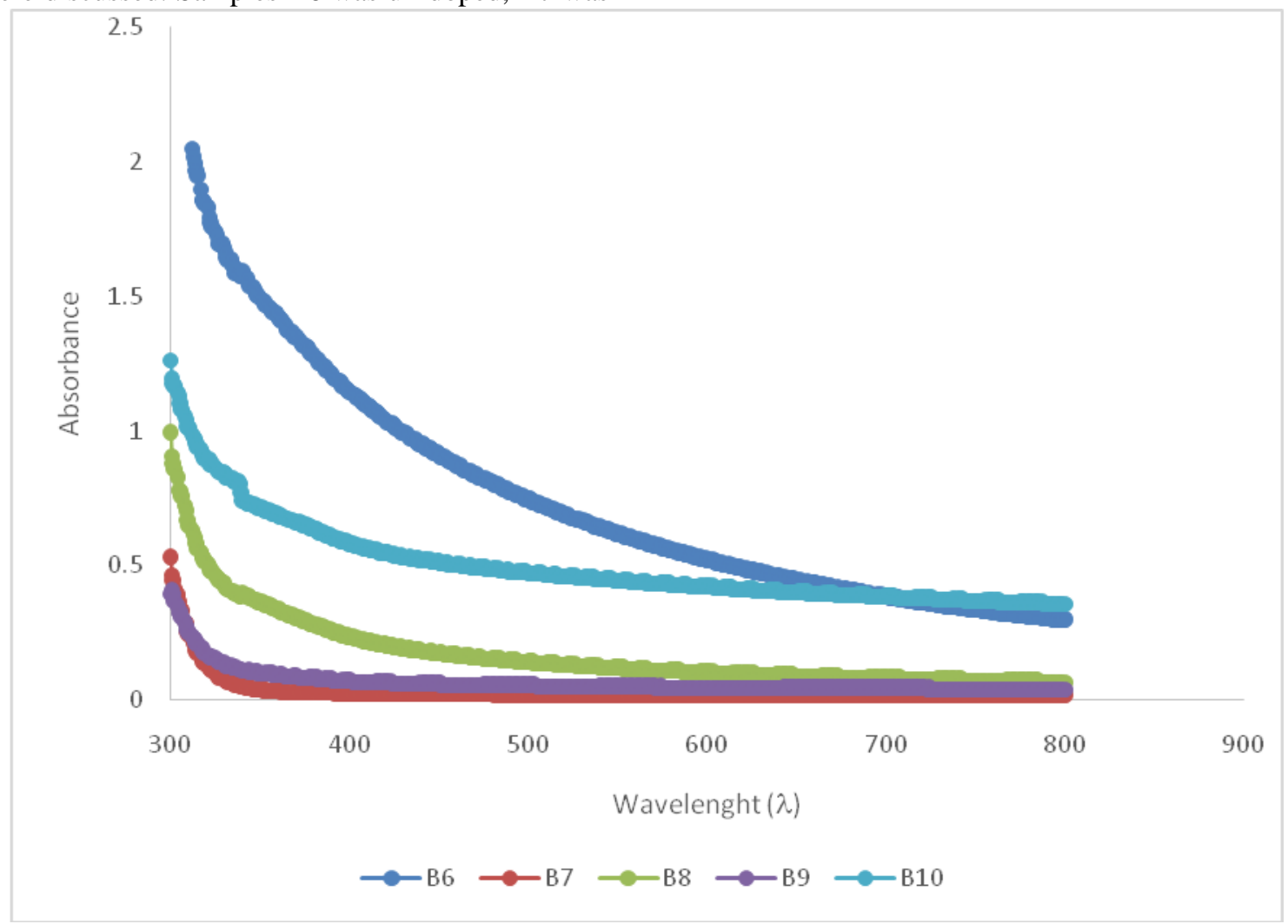

Figure 1: Absorbance versus Wavelength

It was observed that the samples rate of absorption $\mathrm{nm}$ and could not absorb again towards $800 \mathrm{~nm}$. In sample decreased with increased wavelength for samples B6, B8 and B9, absorbance decreased from 0.6 at $300 \mathrm{~nm}$ to 0.05 at 600 B10. Samples B7 decreased from 0.5 at $300 \mathrm{~nm}$ to 0 at 350 $\mathrm{nm}$ and became steady towards $800 \mathrm{~nm}$.

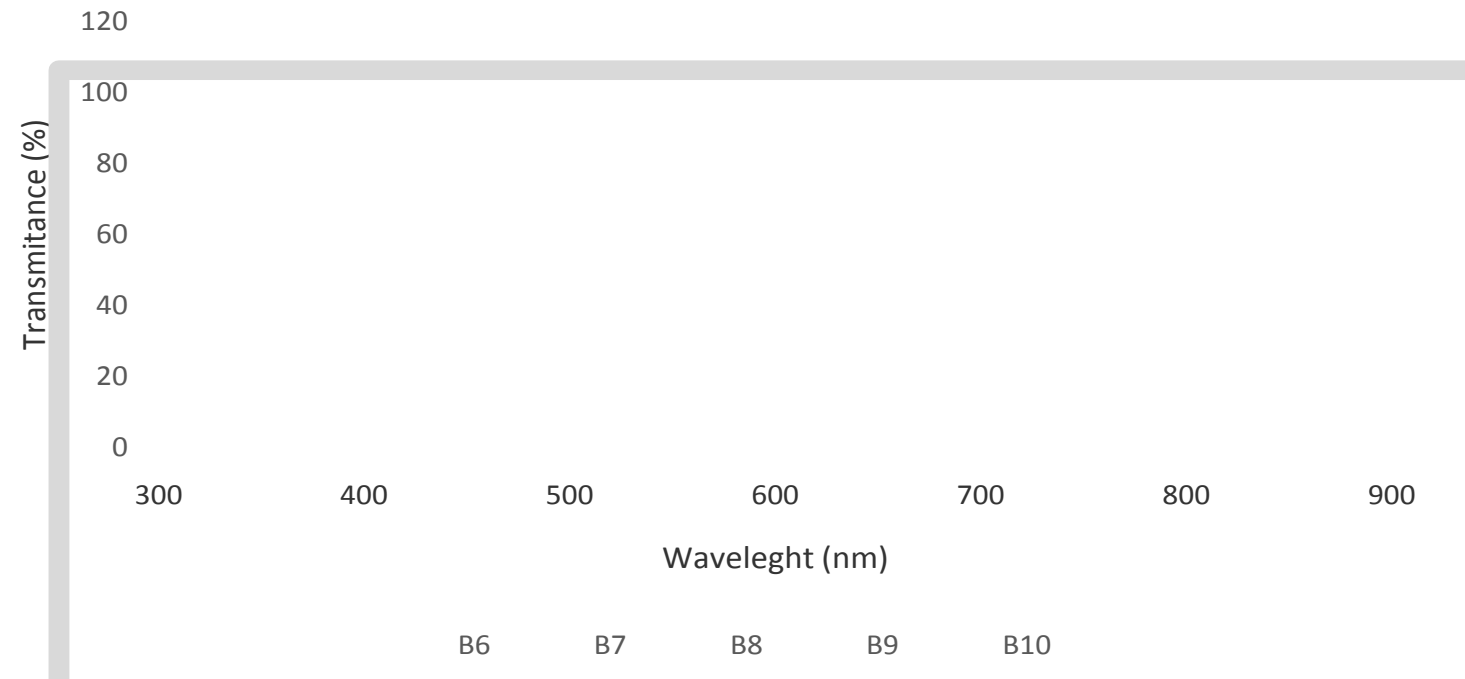

Figure 2: Transmittance versus wavelength

In figure 2 , all the samples were highly transmitting. Sample B6 had the least transmittance. It transmitted lowly from $300-400 \mathrm{~nm}$ and increased progressively to $800 \mathrm{~nm}$. Sample B10, transmitted from 5\% at 300nm and increased to $30 \%$ at $640 \mathrm{~nm}$ and remained steady up to $800 \mathrm{~nm}$. Sample B8 transmitted from $10 \%$ at $300 \mathrm{~nm}$ and increased to $800 \mathrm{~nm}$. Sample B9 transmitted from $40 \%$ at $300 \mathrm{~nm}$ and increased to
$80 \%$ at $400 \mathrm{~nm}$ and remained steady up to $800 \mathrm{~nm}$. Finally, sample B7 had the highest transmittance. It transmitted from $30 \%$ at $300 \mathrm{~nm}$ and increased to $90 \%$ at $350 \mathrm{~nm}$ and remained steady to $800 \mathrm{~nm}$. The samples are highly transmitting from the visible region towards the near infra-red regions and as such can be applied in poultry and solar energy applications,(Okpala V. Uche., et-al., 2012). 


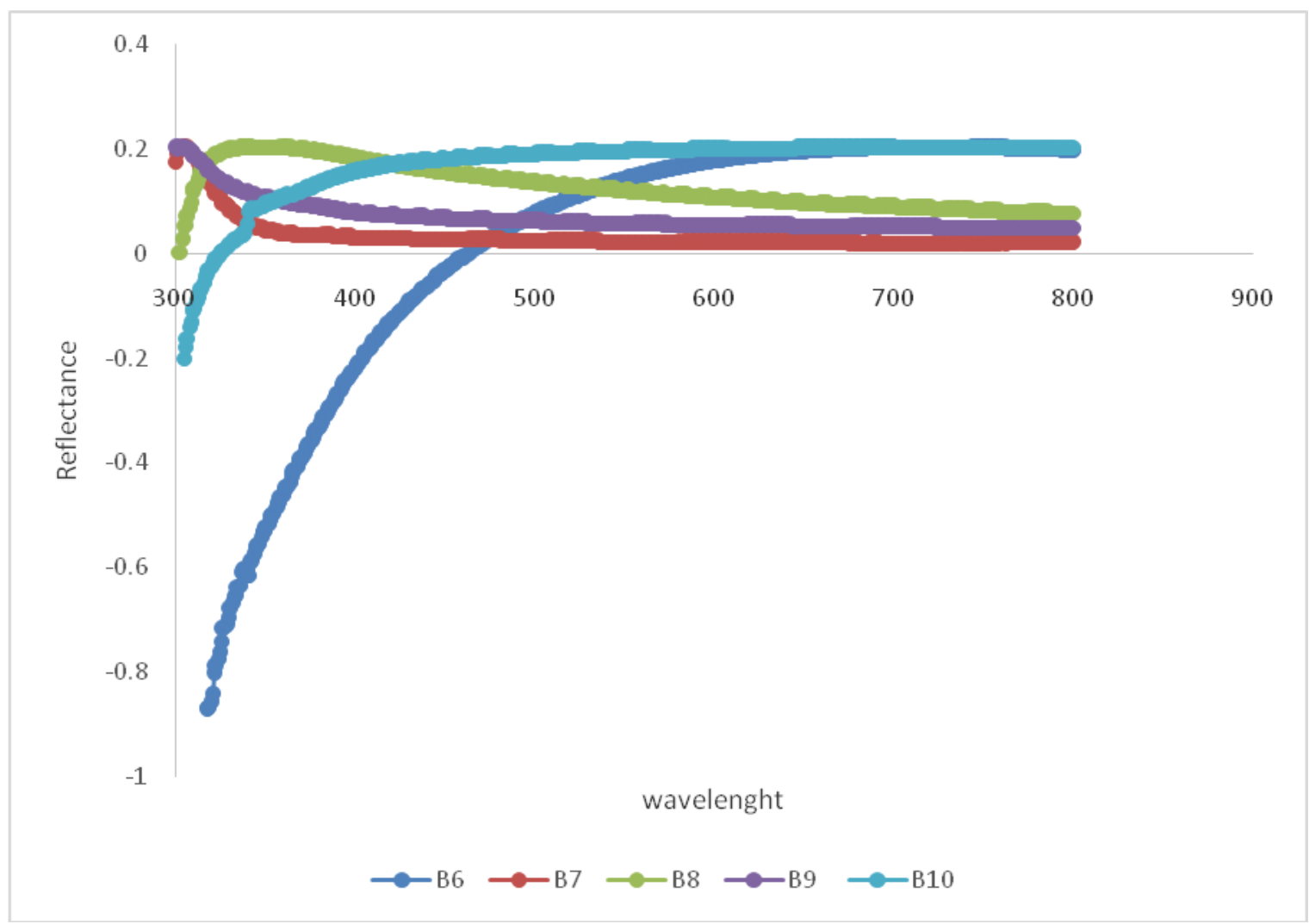

Figure 3: Reflectance for Samples B6 to B10

All the samples were poorly reflecting. Samples B6 has negative reflectance from -0.9 at $340 \mathrm{~nm}$ to 0 at $470 \mathrm{~nm}$ and increased positively up to $600 \mathrm{~nm}$ and remained steadily towards $800 \mathrm{~nm}$. Sample B10 also had negative reflectance of -0.2 at $300 \mathrm{~nm}$ and increased to 0.18 at $400 \mathrm{~nm}$ before it reflected steadily towards $800 \mathrm{~nm}$. The negative value may be due to presence of impurities (dirt) in the process of deposition. Sample B7 had 0.2 reflectance at $300 \mathrm{~nm}$ and decreased to 0 at $680 \mathrm{~nm}$ before it became steady towards 800 $\mathrm{nm}$. B8 had 0 reflectance at $300 \mathrm{~nm}$ and increased to 0.2 at $320 \mathrm{~nm}$ and had a sharp decrease towards $800 \mathrm{~nm}$. Sample B9 had reflectance of 0.2 at $300 \mathrm{~nm}$ and decreased toward 800 $\mathrm{nm}$. The reflectance was too low so it can be applied in making of an antireflection coating of materials, (Edmund, 2007).

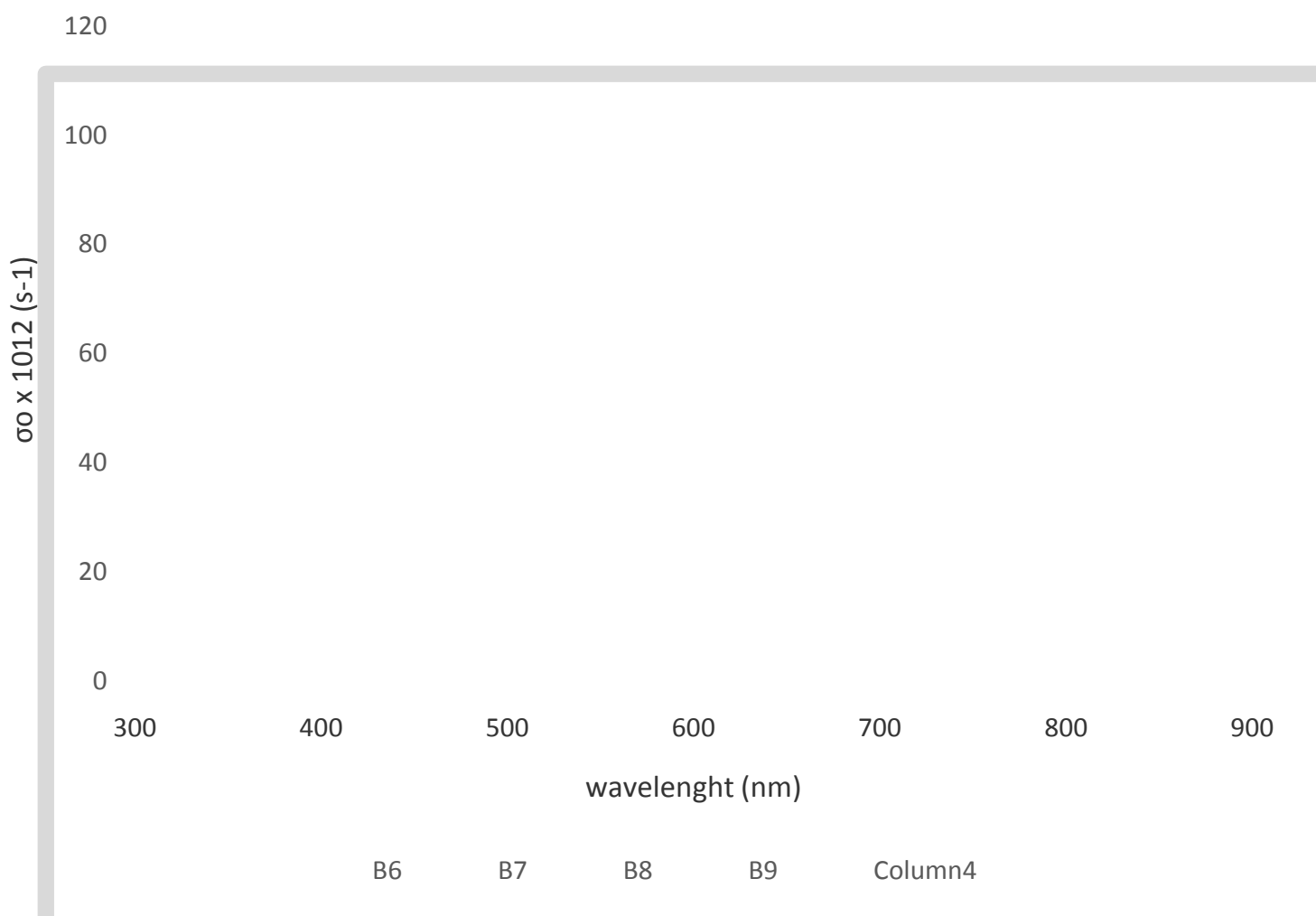

Figure 4: Optical Conductivity for Samples $B_{6}$ to $B_{10}$ 
Sample B6 had optical conductivity of 70 at $480 \mathrm{~nm}$ decreased to 50 at $680 \mathrm{~nm}$. Sample B7 had optical conductivity of 45 at $330 \mathrm{~nm}$ and decreased towards $800 \mathrm{~nm}$. Sample B8 had the highest conductivity of 108 at about 320 $\mathrm{nm}$ and decreased towards $800 \mathrm{~nm}$. Sample B9 had optical conductivity of 45 at $330 \mathrm{~nm}$ and decreased towards $800 \mathrm{~nm}$.
Sample B10 had optical conductivity of 93 at $360 \mathrm{~nm}$ and decreased towards $800 \mathrm{~nm}$.

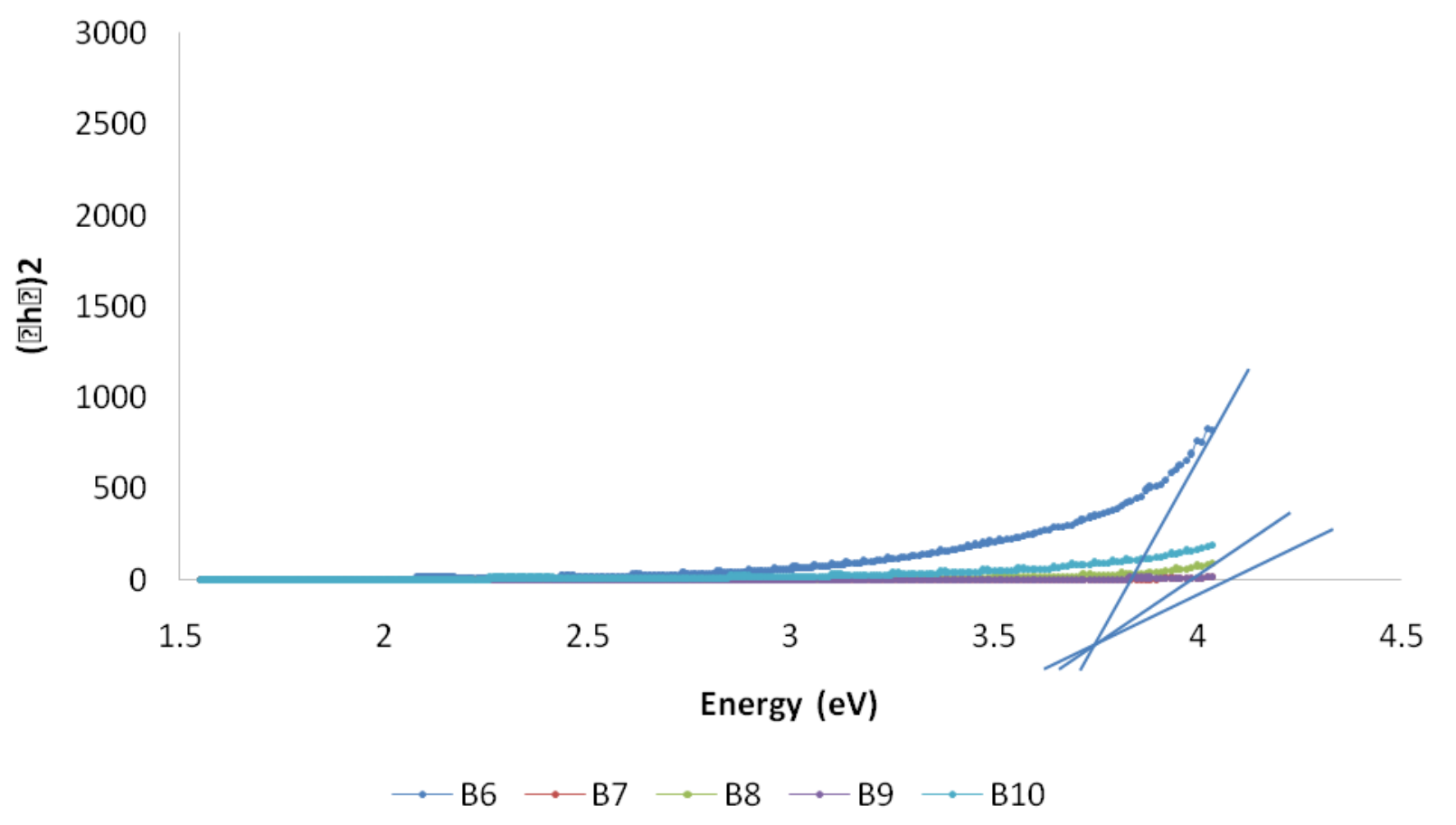

Figure 5: Energy Band Gap for Samples $\mathrm{B}_{6}$ to $\mathrm{B}_{10}$

The films grown were wide band gap materials except for samples B7 and B9 that have no band gaps and as such are not semiconductor materials. This implied that they were metals and can be applied in the production of cooking utensils, electrical wires, pressing irons etc., (Yoshikawa, 2007). Sample B6 has band gap of 3.8 and sample B10 has a bang gap of 3.9 which indicate that they are wide band gap semiconductors and can be used as refractory materials and as heat sink, (Okpala et-al., 2012, E.N. Ufere et-al., 2016and Yacobi B.G., 2004).

3

0

wavelenght $(\mathrm{nm})$

Figure 6 : Refractive Index for Samples B6 to B10 
In Figure 6 , sample B6 had refractive index of I.2 at a wavelength of $460 \mathrm{~nm}$ and increased to 2.8 at a wavelength of $450 \mathrm{~nm}$ before it became steady towards $800 \mathrm{~nm}$.Sample B7 had refractive index of 2.7 at a wavelength of $300 \mathrm{~nm}$ before it decreased towards $800 \mathrm{~nm}$. Sample B8 had refractive index 2.2 at a wavelength of $310 \mathrm{~nm}$ and increased to 2.7 before it decreased towards $800 \mathrm{~nm}$. Sample B9 had refractive index of 2.7 at $300 \mathrm{~nm}$ and decreased towards $800 \mathrm{~nm}$. Sample BI0 had refractive index of 1.75 at $340 \mathrm{~nm}$ and increased to 2.7 towards $800 \mathrm{~nm}$. Materials with high refractive index above 1.8 are good in making lens, optical circuit, optical fibre, antireflective films and coating, optical adhesive, LCD display, waveguide (Hun-Ju Yen and Guey-Sheng Liou, 2010).

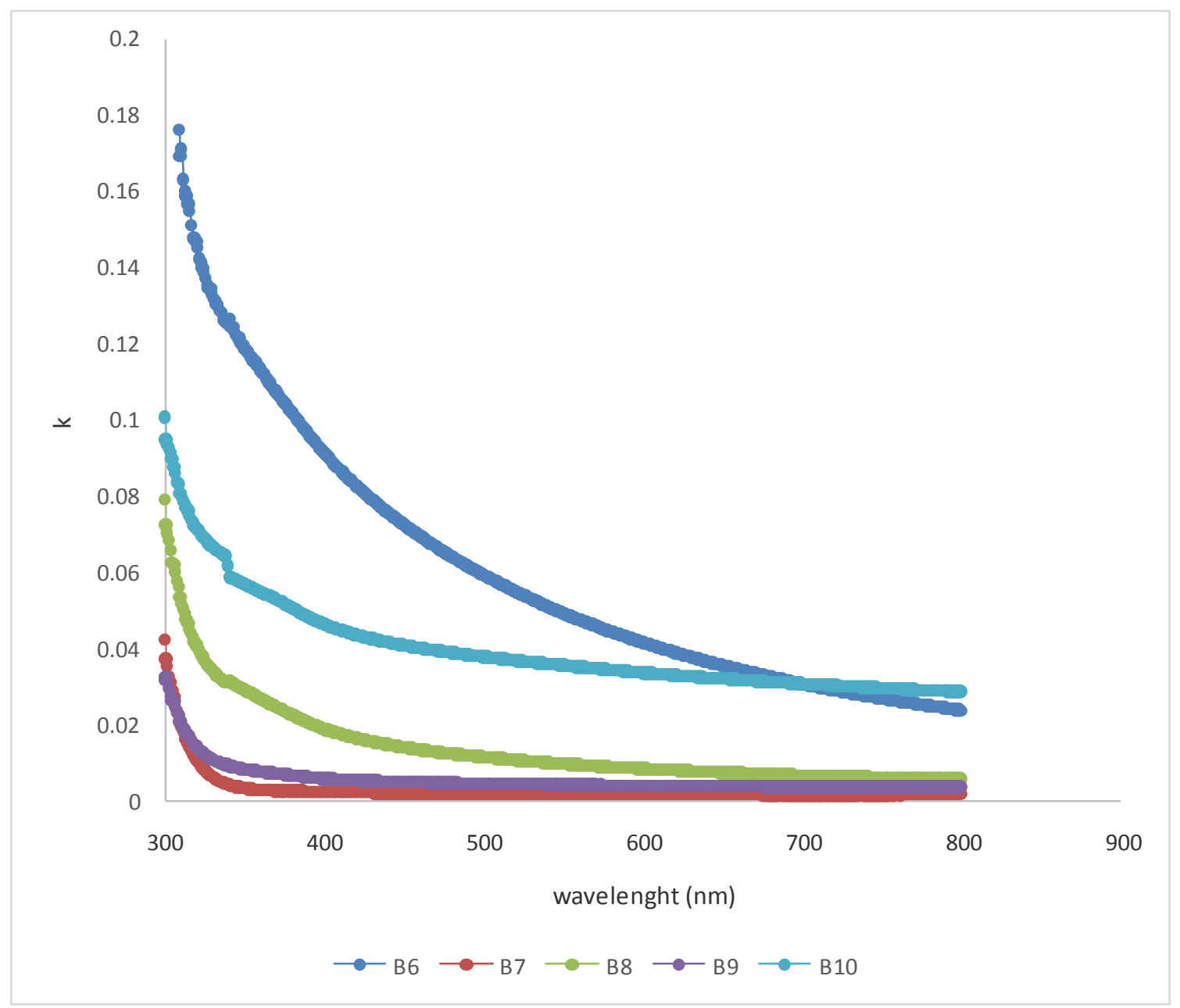

Figure 7 : Extinction Coefficient for Samples $\mathrm{B}_{6}$ to $\mathrm{B}_{10}$

In figure 7 , sample B6 had peak at 0.175 extinction coefficient at wavelength of $310 \mathrm{~nm}$ and decreased towards $800 \mathrm{~nm}$. Sample B7 had extinction coefficient of 0.04 at 300 $\mathrm{nm}$ and decreased towards $800 \mathrm{~nm}$. Sample B8 had refractive index of 0.08 at a wavelength of $300 \mathrm{~nm}$ and decreased towards $800 \mathrm{~nm}$. Sample B9 had refractive index of 0.03 at $300 \mathrm{~nm}$ and decreased towards $800 \mathrm{~nm}$. Sample B10 had refractive index of 0.1 and decreased towards $800 \mathrm{~nm}$. 


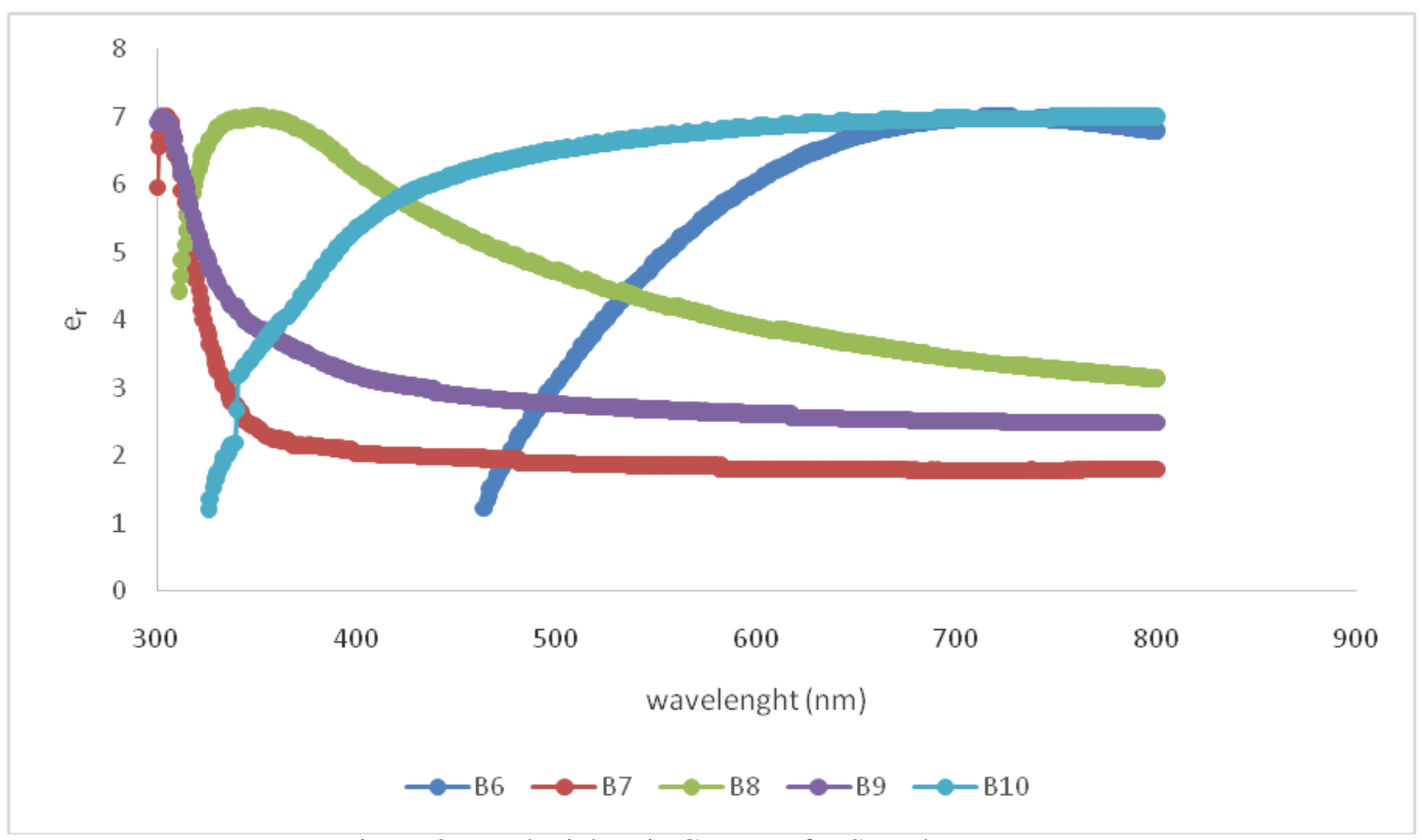

Figure 8 : Real Dielectric Constant for Samples $\mathrm{B}_{5}$ to $\mathrm{B}_{10}$

Figure 8 shows that sample B6 increased from 1 at a wavelength of $320 \mathrm{~nm}$ and increased towards $800 \mathrm{~nm}$. Sample B7 started increasing from 6 at a wavelength of 300 $\mathrm{nm}$ increased to 7 and had a sharp decrease towards $800 \mathrm{~nm}$. Sample B8 started from refractive index of 4 at $320 \mathrm{~nm}$ and increased to 7 before it decreased towards $800 \mathrm{~nm}$. Sample B9 dielectric constant of 7 at a wavelength of $300 \mathrm{~nm}$ and decreased towards $800 \mathrm{~nm}$. Sample BI0 increased from 1 to 6.5 before it became steady towards $800 \mathrm{~nm}$. Materials with high dielectric constant are good for making capacitors while low dielectric constants are good in providing insulations between conductors to minimize lost. (Alfredo, 2005).

\section{CONCLUSION}

Tin (II) Oxide ( $\mathrm{SnO}$ ) doped with oil bean seed extracts showed high transmittance from the visible to near infra-red regions and as such are good for poultry and solar energy applications, (Okpala V. Uche., et-al., 2012).Thehave very low reflectance and as such are good for anti-reflective coating of materials (Edmund, 2001). The sample showed high refractive index in some cases, those with high refractive index above 1.8 can be used for making lenses, optical fibre, antireflective films and coatings, wave guide (Hung-Ju Yen and Guey-Shenglion, 2010).

Energy band gap showed high range between 3.8 to $3.9 \mathrm{eV}$ which is under the range of a semiconductor and can be useful in making of electronic components such as diodes, transistors and building block of logic gate (Yoshikawa, 2007). They are wide band gap materials and as such can be employed in high temperature, high power, high frequency, optoelectronic devices and as heat sink, (Okpala, et-al, 2012;E.N. Ufere et-al., 2016). The samples with zero band gap are metals and can be useful in making of electrical cables, cooking utensils, pressing iron etc., (Pillai, 2009).

\section{REFERENCES}

[1] Akintayo, E.T. and Bayer, E. (2002). Characterization and some possible uses of Plukenetiaconophora and Adenopusbreviflorus seeds and seed oils. Bioresource. Technology,85: 95-97.

[2] Edmund Optics Inc (2007). East Gloucester Pink Barrinton NJ 08007 1380 USA., pp. $32-45$.

[3] Enujiugha, V.N. and Akanbi, C.T. (2005).Compositional changes in African oil bean (Pentaclethramacrophylla Benth) seeds during thermal processing. Pak. Journal of Nutrition, 4: 27-31.

[4] Hung-Ju, Y. and Guey-Sheng, L. (2010). A Facile Approach towards Optically Isotropic, colourless and thermoplastic polyimidothioethers with high refractive index. Journal of material Chemistry, 20: 4080 4089.

[5] Okpala V. Uche, Ezema I Felix and Osuji U. Rose (2012), Synthesis and Characterization of Local Impurities doped Stannous Iodide $\left(\mathrm{SnI}_{2}\right)$ Crystal in Silica Gel, Advances in Applied Science Research,3 (2) 1180.

[6] Okpala V. Uche, Ezema I.Felix and Osuji U. Rose, A Study of the Optical Properties of Un-doped and Potash Doped Lead Chloride Crystal in Silica Gel, Advances in Applied Science Research, 2012, 3(1): 106.

[7] Pillai, S.O. (2009). Band structures of semiconductors. New age international limited,pp. $530-543$.

[8] Peplinski, D.R.; Wozniak, W.T.; Moser, J.B. (1980). Spectral Studies of New Luminophors for Dental Porcelain. Journal of Dental Research. Jdr.iadrjournals.org.,59 (9): 1501-1506.

[9] Yacobi B.G., Semiconductor Materials, (New York: Kluwer Academic Publisher, 2004), 148.

[10] Yoshikawa, A. (2007). Development and Applications of wide band gap semiconductor": In Yoshikawa A, Matsunami, H. Nanishi, Y. (eds.). wide band gap semiconductors. Springer, pp. $2-6$.

[11] E.N. Ufere, U.V. Okpala, U.V. Osonwa (2016). Synthesis and Characterization of un-doped, Raffia Palm and Oil Bean Doped Lead Chloride $\left(\mathrm{PbCl}_{2}\right)$ Crystal in Silica Gel, International Journal of Scientific and Engineering Research, 7 (1): 589.

[12] Zumdahl, S.S. (2009). Chemical Principles 6th Ed. Houghton Mifflin Company, pp. $23-30$. 